\title{
Wtaściwości antyoksydacyjne papryki ostrej odmiany Hungarian yellow
}

\author{
The antioxidant activity of Hungarian yellow hot pepper
}

\author{
Katarzyna Florkowska ${ }^{凶}$, Wiktoria Duchnik, Anna Nowak, Adam Klimowicz
}

Pomorski Uniwersytet Medyczny w Szczecinie, Katedra i Zakład Chemii Kosmetycznej i Farmaceutycznej, al. Powstańców Wlkp. 72, 70-111 Szczecin Pomeranian Medical University in Szczecin, Chair and Department of Cosmetic and Pharmaceutical Chemistry

$\triangle$ katarzyna.florkowska@pum.edu.pl

\begin{abstract}
Introduction: Antioxidants contained in some fruits and vegetables protect organisms against the oxidative stress. This process is an important factor in the pathogenesis of ageing as well as cardiovascular, neoplastic and neurodegenerative diseases. Hot pepper (Capsicum annuum L.) is important vegetable and is used as a meal and as a spice worldwide. Its fresh fruits are the valuable source of vitamin $\mathrm{C}, \mathrm{A}$, macro- and microelements, carotenoids as well as polyphenols.

The aim of the study was to evaluate the antioxidant activity and assimilation pigment content in the alcoholic and aqueous extracts of hot peeper fruits.

Materials and methods: Raw material consisted of Hungarian yellow hot pepper fresh fruits with seeds. Ultrasound-assisted extraction (15, 30 and $60 \mathrm{~min}$ ) was applied to obtain methanolic, ethanolic, isopropanolic and aqueous extracts. Antioxidant activity was evaluated with 2,2-diphenyl-1-picrylhydrazyl (DPPH) and ferric ion reducing antioxidant parameter (FRAP) methods,
\end{abstract}

whereas the assimilation pigments content in the fruits using Arnon method.

Results: Assimilation pigment contents, such as chlorophylls $\mathrm{a}, \mathrm{b}$ and carotenoids, were found in Capsicum annuum L. fresh fruits. Moreover, slightly more carotenoids as compared to total chlorophylls $(\mathrm{a}+\mathrm{b})$ were determined. Antioxidant activity of hot pepper extracts was observed. The highest activity, evaluated with DPPH method, was found for 60 min methanolic extracts. In contrary, all extracts prepared in isopropyl alcohol, were characterized by the highest antioxidant potential evaluated with FRAP method.

Conclusion: Antioxidant activity and assimilation pigments content of hot pepper fresh fruits extracts were observed, so, they can be a useful source of antioxidants to apply in cosmetic and pharmaceutical industry.

Keywords: hat pepper; antioxidant activity; DPPH; FRAP; assimilation pigment.

\section{ABSTRAKT}

Wstęp: Antyoksydanty zawarte w niektórych owocach i warzywach chronią organizm przed stresem oksydacyjnym, który odgrywa główną rolę w patogenezie starzenia oraz chorób układu sercowo-naczyniowego, nowotworowych i neurodegeneracyjnych. Papryka jest ważnym warzywem, wykorzystywanym przede wszystkim jako potrawa, ale także jako przyprawa. Świeże owoce są cennym źródłem witaminy C i A, makro- i mikroelementów, karotenoidów oraz polifenoli.

Celem pracy była ocena aktywności antyoksydacyjnej oraz zawartości barwników asymilacyjnych alkoholowych i wodnych wyciągów z owoców papryki ostrej.

Materiały i metody: Materiał roślinny stanowiły świeże okrywy nasienne papryki ostrej odmiany Hungarian yellow wraz z nasionami. Wyciągi sporządzono metodą ekstrakcji wspomaganej ultradźwiękami przez okres 15, 30 i 60 min, przy czym rozpuszczalnikami były alkohole metylowy, etylowy i izopropylowy oraz woda. Aktywność antyoksydacyjną mierzono metodą z użyciem odczynnika 2,2-difenylo-1-pikrylohydrazylu (DPPH) oraz metodą oznaczania zdolności redukowania jonów żelaza (FRAP), zaś zawartość barwników asymilacyjnych metodą Arnona.

Wyniki: Świeże owoce papryki charakteryzowały się zawartością barwników asymilacyjnych, takich jak chlorofil a, b oraz karotenoidy, przy czym stwierdzono nieco większą ilość karotenoidów w porównaniu z chlorofilem całkowitym $(a+b)$. Wyciągi z materiału roślinnego miały aktywność antyoksydacyjną. Najwyższe wartości, mierzone metodą DPPH, stwierdzono dla prób ekstrahowanych stężonym metanolem przez $60 \mathrm{~min}$. W przypadku metody FRAP najwyższym potencjałem antyoksydacyjnym charakteryzowały się wszystkie ekstrakty sporządzone w alkoholu izopropylowym.

Wnioski: Ekstrakty ze świeżych owoców papryki wykazują aktywność antyoksydacyjną oraz zawierają barwniki asymilacyjne, dlatego mogą być użyteczne jako surowce antyoksydacyjne w preparatach kosmetycznych i farmaceutycznych.

Słowa kluczowe: papryka ostra; aktywność antyoksydacyjna; DPPH; FRAP; barwniki asymilacyjne.

\section{WSTĘP}

Papryka roczna (Capsicum annuum L.), należąca do rodziny psiankowatych (Solanaceae), zwana jest potocznie pieprzowcem rocznym, papryką owocową czy pieprzowcem ostrym. Należy do najbardziej popularnych warzyw na świecie ze względu na połączenie koloru, smaku i wartości odżywczych [1]. Pochodzi z Ameryki Północnej i Południowej, dlatego też najlepiej rośnie 
w ciepłym i suchym klimacie [2]. Częścią jadalną jest jagoda, mająca skórzastą okrywę o różnym kolorze i kształcie. Odmiany słodkie mają owoce większe, bardziej owalne, natomiast ostre - mniejsze i wydłużone, często w postaci stożka. Wśród najczęściej spotykanych kolorów okrywy nasiennej można wyróżnić czerwony, zielony, żółty oraz pomarańczowy [3].

Świeża papryka zawiera dużo cennych składników, do których głównie zaliczają się witaminy, w szczególności witamina $\mathrm{C}$, sole mineralne oraz makro- i mikroelementy. Bardzo ważnym składnikiem, nadającym barwę i mającym jednocześnie właściwości zdrowotne, są barwniki występujące w okrywie nasiennej. Czerwona papryka zawiera głównie $\beta$-karoten oraz utlenione karotenoidy, tj. kapsantynę, kapsorubinę i kryptokapsynę [4]. Za zielony kolor papryki odpowiadają chlorofil i karotenoidy, za pomarańczowy - $\alpha$ - i $\beta$-karoten, luteina i $\beta$-kryptoksantyna [5], z kolei żółta papryka bogata jest w luteinę [6]. Innymi ważnymi składnikami papryki są liczne związki fenolowe oraz flawonoidy takie jak kwercetyna i luteolina. Wszystkie te związki wykazują korzystny wpływ na zdrowie dzięki zdolnościom ochrony komórek przed stresem oksydacyjnym. Liczne badania wykazały, iż owoce papryki rocznej mają działanie przeciwrodnikowe [3, 6, 7], dzięki czemu mogą zapobiegać rozwojowi nowotworów, chorób układu krążenia, zaćmie, cukrzycy, chorobie Alzheimera czy Parkinsona [1]. Wymienione substancje przeciwutleniające zapobiegają również utlenianiu składników lipidowych w komórkach mózgu, które uważane są za niezbędne do jego prawidłowego funkcjonowania [8].

W przemyśle spożywczym oraz również farmaceutycznym i kosmetycznym bardzo ważną rolę odgrywają tzw. odmiany chili, reprezentowane przez rodzaj Capsicum, które charakteryzują się bardzo wysoką zawartością alkaloidu o piekącym smaku - kapsaicyny. Ze względu na obecność tego związku chili stosowana jest głównie w przemyśle spożywczym jako przyprawa nadająca potrawom ostry smak. W farmacji i kosmetologii kapsaicyna znajduje zastosowanie w preparatach rozgrzewających skórę i okoliczne tkanki [9].

Celem pracy była ocena zawartości barwników asymilacyjnych oraz aktywności antyoksydacyjnej alkoholowych i wodnych ekstraktów ze świeżych okryw żółtej papryki ostrej odmiany Hungarian yellow wraz z nasionami.

\section{MATERIAŁY I METODY}

2,4,6-tripirydylo-S-triazyna, 2,2-difenylo-1-pikrylohydrazyl (DPPH) oraz kwas 6-hydroksy-2,5,7,8-tetrametylochromano-2-karboksylowy (troloks) pochodziły z firmy Sigma Aldrich, USA; chlorek żelaza(III) heksahydrat i siarczan(VI) żelaza(II) heptahydrat - z firmy Merck, Darmstadt, Niemcy; lodowaty kwas octowy, bezwodny octan sodu, kwas solny 36\%, alkohol etylowy, alkohol metylowy, alkohol izopropylowy oraz aceton (wszystkie o czystości do analizy) pochodziły z firmy Chempur, Piekary Śląskie.

Żółta papryka ostrej odmiany Hungarian yellow pochodziła z uprawy własnej. Do badań wykorzystano całą okrywę nasienną wraz z nasionami. W celu pozyskania ekstraktów użyto alkoholu etylowego w stężeniach 40\% (v/v), 70\% (v/v) i 96\% (v/v), alkoholu metylowego w stężeniach 40\% (v/v), 70\% (v/v) i 99,8\% (v/v) oraz alkoholu izopropylowego w stężeniach $40 \%$ (v/v), 70\% (v/v) i 99,7\% (v/v), a także wody. Przygotowany surowiec ekstrahowano poszczególnymi rozpuszczalnikami w łaźni ultradźwiękowej przez okres 15, 30 i 60 min.

Ocenę właściwości antyoksydacyjnych przeprowadzono z wykorzystaniem metod DPPH oraz oznaczania zdolności redukowania jonów żelaza (FRAP). Sposób wykonania analiz właściwości antyoksydacyjnych był analogiczny do stosowanego w uprzednio prowadzonych badaniach $[10,11,12]$. Wszystkich powyższych pomiarów absorbancji dokonano za pomocą spektrofotometru Spectroquant Pharo 300 (Merck). W przypadku oznaczeń metodą DPPH pomiarów dokonano przy długości fali $517 \mathrm{~nm}$. Aktywność antyoksydacyjną (zdolność do eliminacji wolnych rodników - radical scavenging activity RSA) wyrażono w procentach oraz jako równoważnik troloksu, czyli stężenie troloksu wykazujące taką samą aktywność jak badana próbka.

W przypadku metody FRAP analizowano zdolność badanych ekstraktów do redukcji jonów żelaza $\mathrm{Fe}^{3+} \mathrm{z}$ kompleksu żelazowo-2,4,6-tri(2-pirydylo)-s-triazyny. Wyniki wyrażono $\mathrm{w} \mathrm{mg} \mathrm{FeSO}{ }_{4} \mathrm{w}$ przeliczeniu na g surowca.

Zawartość barwników asymilacyjnych, tj. chlorofilu całkowitego i karotenoidów, oznaczono metodą Arnona i wsp. [13] w modyfikacji Lichtenthalera i Wellburna [14], wykorzystując do badań świeże okrywy nasienne papryki. W celu ekstrakcji barwników asymilacyjnych zastosowano aceton $80 \%$ (v/v), a oznaczeń dokonano przy długościach fali 440, 645 i 663 $\mathrm{nm}$. Otrzymane wyniki przedstawiono jako średnie arytmetyczne £odchylenie standardowe. Analiza statystyczna została wykonana jednoczynnikowym testem ANOVA. Istotność różnic określono pomiędzy poszczególnymi czasami ekstrakcji, w obrębie każdego rozpuszczalnika, za pomocą testu Tukeya (jako poziom istotności przyjęto $\mathrm{p}<0,05$ ). W celu opracowania danych statystycznych użyto programu Statistica 12 (Statsoft).

\section{WYNIKI}

Na rycinie 1 przedstawiono zawartość barwników asymilacyjnych obejmujących chlorofil a i b, chlorofil całkowity oraz karotenoidy w owocach papryki żółtej, wyrażoną w $\mu \mathrm{g} / \mathrm{g}$ świeżej masy (ś.m.) surowca. Świeże okrywy badanej rośliny charakteryzowały się wysoką zawartością karotenoidów wynoszącą 158,61 $\mu \mathrm{g} / \mathrm{g}$ ś.m. surowca, co stanowiło 52\% wszystkich barwników asymilacyjnych. W przypadku chlorofilu całkowitego zawartość tego barwnika była na poziomie $48 \%$ (144,57 $\mu \mathrm{g} / \mathrm{g}$ ś.m. surowca), przy czym zawartość obydwu chlorofili (a i b) była na podobnym poziomie wynoszącym dla chlorofilu a $-67,03 \mu \mathrm{g} / \mathrm{g}$ ś.m. surowca, natomiast dla chlorofilu b-77,54 $\mu \mathrm{g} / \mathrm{g}$ ś.m. surowca (ryc. 1).

Owoce papryki charakteryzowały się umiarkowaną aktywnością antyoksydacyjną (tab. 1, ryc. 2). Wyniki oznaczeń ekstraktów metodą DPPH wskazują na różne działanie antyoksydacyjne, uzależnione przede wszystkim od czasu ekstrakcji oraz zastosowanego rozpuszczalnika. Zdolność zmiatania 


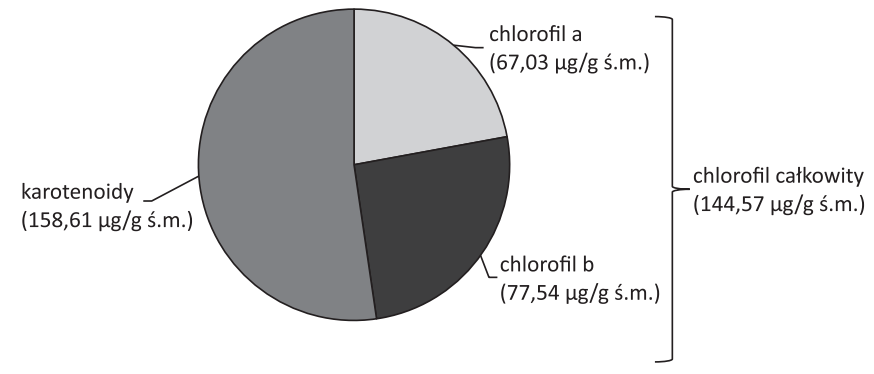

RYCINA 1. Zawartość barwników asymilacyjnych w świeżych owocach papryki żółtej wyrażona w $\mu \mathrm{g} / \mathrm{g}$ świeżej masy (ś.m.)

TABELA 1. Średnie ( $\pm S D)$ właściwości przeciwutleniające wyciągów ze świeżych owoców papryki ostrej odmiany Hungarian yellow oznaczone metodą DPPH, wyrażone jako \% RSA

\begin{tabular}{|c|c|c|}
\hline Rozpuszczalnik & $\begin{array}{c}\text { Czas ekstrakcji } \\
\text { (min) }\end{array}$ & $\begin{array}{l}\text { RSA } \\
(\%)\end{array}$ \\
\hline \multirow{3}{*}{ Etanol 40\% } & 15 & $12,970 \pm 0,007 b$ \\
\hline & 30 & $13,564 \pm 0,003 b$ \\
\hline & 60 & $15,115 \pm 0,004 \mathrm{a}$ \\
\hline \multirow{3}{*}{ Etanol 70\% } & 15 & $15,742 \pm 0,006 \mathrm{~b}$ \\
\hline & 30 & $16,931 \pm 0,004 b$ \\
\hline & 60 & $20,594 \pm 0,007 a$ \\
\hline \multirow{3}{*}{ Etanol 96\% } & 15 & $13,894 \pm 0,006 \mathrm{c}$ \\
\hline & 30 & $18,944 \pm 0,005 b$ \\
\hline & 60 & $21,518 \pm 0,005 a$ \\
\hline \multirow{3}{*}{ Metanol 40\% } & 15 & $18,812 \pm 0,006 a b$ \\
\hline & 30 & $20,033 \pm 0,005 \mathrm{a}$ \\
\hline & 60 & $21,056 \pm 0,004 a$ \\
\hline \multirow{3}{*}{ Metanol 70\% } & 15 & $19,834 \pm 0,005 c$ \\
\hline & 30 & $23,267 \pm 0,005 b$ \\
\hline & 60 & $24,818 \pm 0,006 a$ \\
\hline \multirow{3}{*}{ Metanol stężony } & 15 & $24,785 \pm 0,007 c$ \\
\hline & 30 & $30,825 \pm 0,008 b$ \\
\hline & 60 & $34,488 \pm 0,005 a$ \\
\hline \multirow{3}{*}{ Izopropanol 40\% } & 15 & $12,112 \pm 0,009 b$ \\
\hline & 30 & $9,439 \pm 0,056 \mathrm{c}$ \\
\hline & 60 & $14,686 \pm 0,012 \mathrm{a}$ \\
\hline \multirow{3}{*}{ Izopropanol 70\% } & 15 & $10,561 \pm 0,004 b$ \\
\hline & 30 & $15,874 \pm 0,004 \mathrm{a}$ \\
\hline & 60 & $16,667 \pm 0,004 \mathrm{a}$ \\
\hline \multirow{3}{*}{ Izopropanol stężony } & 15 & $11,782 \pm 0,004 b$ \\
\hline & 30 & $12,376 \pm 0,004 b$ \\
\hline & 60 & $13,762 \pm 0,005 a$ \\
\hline \multirow{3}{*}{ Woda } & 15 & $10,033 \pm 0,003 c$ \\
\hline & 30 & $16,369 \pm 0,004 b$ \\
\hline & 60 & $18,976 \pm 0,004 \mathrm{a}$ \\
\hline
\end{tabular}

Wartości oznaczone różnymi literami różnią się istotnie statystycznie w obrębie czasu ekstrakcji. Poziom istotności: $\alpha=0,05 ; n=3$ wolnych rodników wykazana przy wykorzystaniu tej metody

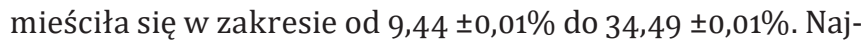
wyższy wynik zaobserwowano w przypadku ekstraktu wykonanego w stężonym metanolu, z wykorzystaniem ultradźwięków przez okres $60 \mathrm{~min}-34,49 \pm 0,27 \%$, co odpowiadało $0,27 \pm 0,01 \mathrm{mg}$ troloksu/g surowca. Nieznacznie niższą wartość stwierdzono w przypadku ekstraktów przygotowanych w tym samym rozpuszczalniku, ekstrahowanych przez $30 \mathrm{~min}(30,83$ $\pm 0,01 \%)$. Wyciągi metanolowe, sporządzone zarówno w 40\% (v/v), jak i 70\% (v/v) alkoholu, wykazywały dość dobrą zdolność do zmiatania wolnych rodników - wartość RSA utrzymywała się przeważnie powyżej 20\%. Stosunkowo niską aktywnością antyoksydacyjną charakteryzowały się wyciągi etanolowe i izopropanolowe, niezależnie od stężenia rozpuszczalnika. W grupach tych najwyższe wartości zaobserwowano w wyciągach sporządzonych w czasie 60 min, zarówno w stężonym etanolu, jak i w 70\% - RSA wynosił odpowiednio 21,52 $\pm 0,01 \%$ oraz $20,59 \pm 0,01 \%$ i różnił się istotnie od pozostałych czasów ekstrakcji. W przypadku wyciągów wodnych aktywność antyoksydacyjna była zróżnicowana - najwyższa dla ekstraktów 60-minutowych $(18,98 \pm 0,01 \%)$, następnie 30-minutowych $(16,37$ $\pm 0,01 \%)$, zaś najniższa dla wyciągów 15-minutowych - zaledwie 10,03 $\pm 0,03 \%$ (tab. 1).

Wyniki otrzymane metodą FRAP, oceniające zdolność redukcji jonów żelaza $\mathrm{Fe}^{3+}$ do $\mathrm{Fe}^{2+}$, przedstawiono na rycinie 3. Uzyskane wartości dotyczące zdolności redukcyjnych były dość rozbieżne i wahały się w granicach od 0,70 $\pm 0,03 \mathrm{mg} \mathrm{FeSO}_{4} /$ g surowca do 13,65 $\pm 0,39 \mathrm{mg} \mathrm{FeSO}_{4} / \mathrm{g}$ surowca. Najlepsze zdolności redukcyjne zaobserwowano dla ekstraktów sporządzonych w stężonym alkoholu izopropylowym. Po zastosowaniu tego rozpuszczalnika nie wykazano istotnych różnic ze względu na czas ekstrakcji, jednak najwyższą wartość stwierdzono dla wyciągów 60-minutowych - 13,65 $\pm 0,39 \mathrm{mg} \mathrm{FeSO}_{4} /$ g surowca, następnie 30-minutowych $\left(11,85 \pm 0,35 \mathrm{mg} \mathrm{FeSO}_{4} /\right.$ g surowca) i 15-minutowych $\left(10,71 \pm 0,31 \mathrm{mg} \mathrm{FeSO}_{4} / \mathrm{g}\right.$ surowca). Nieznacznie niższe wartości odnotowano dla wszystkich ekstraktów sporządzonych w stężonym metanolu przy wszystkich czasach ekstrakcji (15, 30 i $60 \mathrm{~min}$ ). W tym przypadku wyciągi ekstrahowane przez 30 i 60 min wykazały zdolność redukcyjną na poziomie 10,01 $\pm 0,28 \mathrm{mg} \mathrm{FeSO}_{4} / \mathrm{g}$ surowca (60 min) i 9,35 $\pm 0,27 \mathrm{mg}$ $\mathrm{FeSO}_{4} / \mathrm{g}$ surowca (30 min) oraz nieco niższą dla $15 \mathrm{~min}-8,44$ $\pm 0,25 \mathrm{mg} \mathrm{FeSO}_{4} / \mathrm{g}$ surowca. Wyciągi wodne okazały się najmniej wartościowe pod względem zdolności redukcyjnych, gdyż otrzymane wyniki były najniższe spośród wszystkich ekstraktów i wynosiły odpowiednio 0,69 £0,02 $\mathrm{mg} \mathrm{FeSO}_{4} / \mathrm{g}$ surowca dla czasu ekstrakcji $60 \mathrm{~min}, 0,99 \pm 0,02 \mathrm{mg} \mathrm{FeSO}_{4} / \mathrm{g}$ surowca w przypadku próbek ekstrahowanych 30 min, 0,63 $\pm 0,03 \mathrm{mg} \mathrm{FeSO}_{4} / \mathrm{g}$ surowca dla najkrótszego czasu ekstrakcji-15 min (ryc. 3).

\section{DYSKUSJA}

W badaniach własnych podjęto próbę oceny aktywności antyoksydacyjnej wyciągów ze świeżych owoców papryki ostrej 


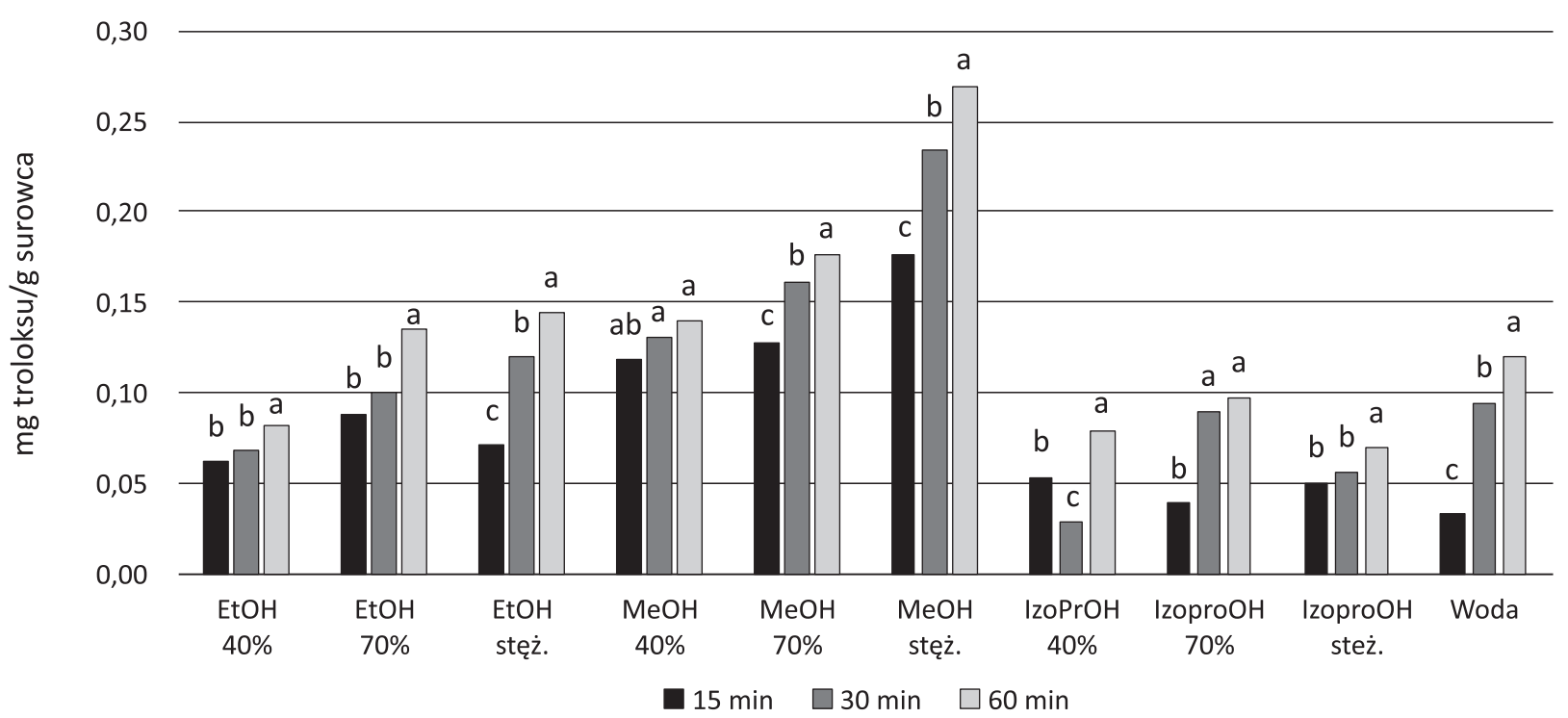

Wartości oznaczone różnymi literami różnią się istotnie statystycznie w obrębie czasu ekstrakcji. Poziom istotności: $\alpha=0,05 ; n=3$

RYCINA 2. Średnia aktywność antyoksydacyjna świeżych owoców papryki ostrej, odmiany Hungarian yellow, oznaczona metodą DPPH, wyrażona w mg troloksu/g surowca

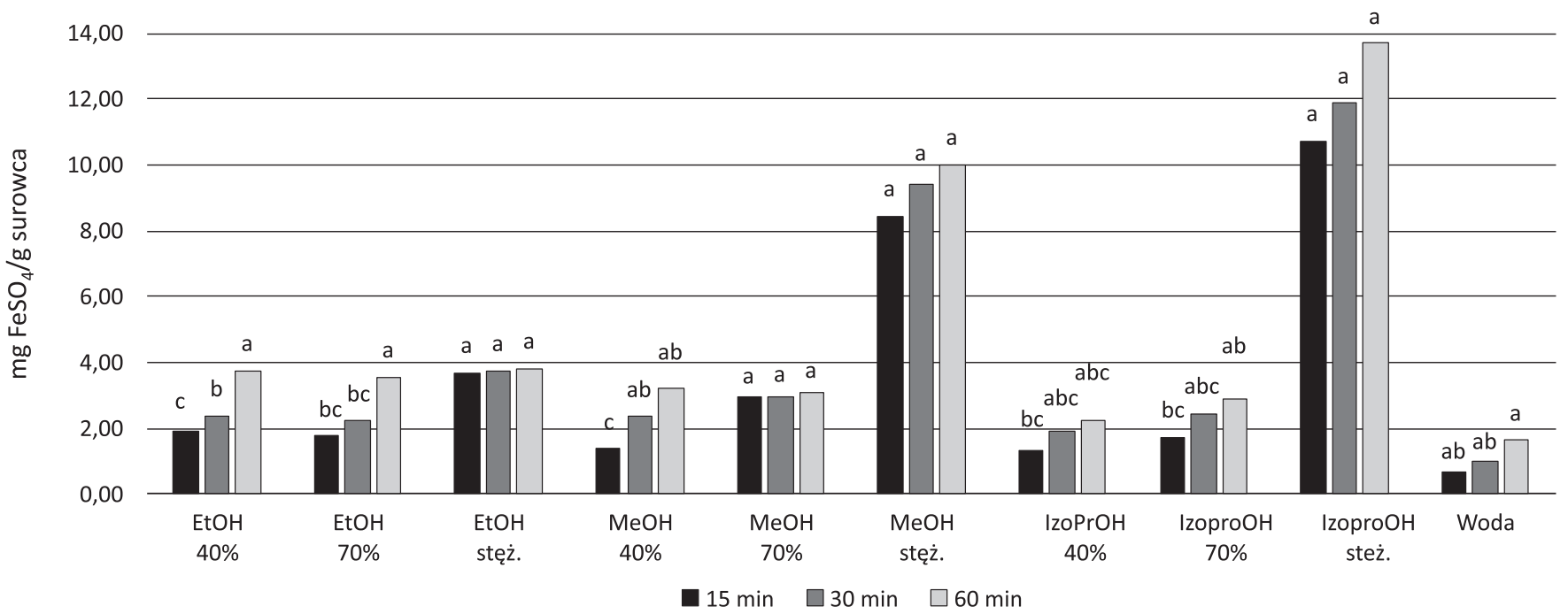

Wartości oznaczone różnymi literami różnią się istotnie statystycznie w obrębie czasu ekstrakcji. Poziom istotności: $\alpha=0,05 ; n=3$

RYCINA 3. Średnia aktywność antyoksydacyjna świeżych owoców papryki ostrej, odmiany Hungarian yellow, oznaczona metodą FRAP, wyrażona w $\mathrm{mg} \mathrm{FeSO}_{4} / \mathrm{g}$ surowca

odmiany Hungarian yellow. Surowiec ekstrahowano w ciągu 15, 30 lub 60 min 4 rozpuszczalnikami o 3 różnych stężeniach, tj. etanolem, metanolem, izopropanolem w stężeniach $40 \%$ (v/v), $70 \%$ (v/v) oraz stężonym, a także wodą, korzystając z łaźni ultradźwiękowej. W badaniach oznaczono aktywność antyoksydacyjną metodami DPPH oraz FRAP, a także oceniono zawartość barwników asymilacyjnych takich jak chlorofil a, chlorofil b, chlorofil całkowity oraz karotenoidy.

Owoce papryki odmian ostrych, ze względu na smak, są ważnym produktem wykorzystywanym przede wszystkim jako przyprawa do potraw. Surowiec ten jest bogaty m.in. w witaminę C, prowitaminę A oraz karotenoidy - substancje mające właściwości antyoksydacyjne [15, 16, 17, 18]. Jednymi z ważniejszych składników odpowiedzialnych za barwę skórki owoców są barwniki asymilacyjne, do których zaliczamy chlorofile oraz karotenoidy. Te pierwsze nadają zielony kolor skórce owoców, natomiast karotenoidy, wśród których wyróżniamy karoteny i ksantofile - barwy od żółtej do pomarańczowej [5].

W badaniu własnym stwierdzono wysoką zawartość barwników asymilacyjnych takich jak karotenoidy oraz chlorofile. Nieznacznie większy udział miały karotenoidy - 158,6 $\mu \mathrm{g} / \mathrm{g}$ ś.m., co stanowi 52\% ogólnej zawartości barwników, w porównaniu z chlorofilem całkowitym - 144,6 $\mu \mathrm{g} / \mathrm{g}$ (48\%) - rycina 1. Odmienny wynik dotyczący barwników asymilacyjnych uzyskali Kim i wsp., którzy wykazali zawartość chlorofilu całkowitego na poziomie 7,58 $\mu \mathrm{g} / \mathrm{g}$ suchej masy oraz karotenoidów $27,30 \mu \mathrm{g} / \mathrm{g}$ suchej masy [6]. Autorzy ci badali jednak barwniki w suchej masie, co mogło być przyczyną obserwowanej niższej 
zawartości barwników asymilacyjnych, szczególnie chlorofilu, który znajduje się w największej ilości w surowcu świeżym, natomiast podczas różnych zabiegów technologicznych ulega degradacji [19]. Ponadto zastosowali oni do ekstrakcji stężony aceton, natomiast $\mathrm{w}$ badaniach własnych zastosowany był rozpuszczalnik $80 \%$ (v/v), który mógł w nieco innym stopniu wyekstrahować badane substancje. Zawartość barwników w owocach papryki może być różna, w zależności od odmiany. Paradiković i wsp. stwierdzili, iż ogólna zawartość karotenoidów w papryce żółtej słodkiej mieściła się w granicach 0,38-0,55 g/kg ś.m., natomiast chlorofilu całkowitego 1,88$3,24 \mathrm{~g} / \mathrm{kg}$ ś.m. [7]. Sun i wsp. badali zawartość poszczególnych barwników w 4 rodzajach owoców papryki słodkiej (zielonej, żółtej, czerwonej oraz pomarańczowej). Papryka czerwona charakteryzowała się wyższą zawartością takich barwników jak $\beta$-karoten, kapsantyna, kwercetyna, luteolina w porównaniu z papryką żółtą [5].

W badaniu własnym oznaczono aktywność przeciwutleniającą ekstraktów z owoców papryki ostrej z wykorzystaniem metod DPPH oraz FRAP. W przypadku metody DPPH ekstrakt z badanego surowca wykazał umiarkowaną zdolność antyoksydacyjną, wyrażoną w \% RSA. Najwyższą wartość stwierdzono dla wyciągów sporządzonych w stężonym metanolu, ekstrahowanych przy użyciu łaźni ultradźwiękowej przez 60 min $(34,49 \%)$. Z przeprowadzonych analiz wynika, że istotny wpływ na działanie przeciwrodnikowe otrzymanych wyciągów ma czas ekstrakcji, najwyższą bowiem wartość zaobserwowano w przypadku najdłużej trwającej ekstrakcji - 60 min - dla wszystkich zastosowanych rozpuszczalników (tab. 1). W piśmiennictwie można znaleźć doniesienia na temat działania przeciwrodnikowego owoców papryki, jednak w analizach wykorzystywane są głównie owoce słodkie, często spożywane w stanie surowym $[3,5,6,7,20]$. Na zdolność zmiatania wolnych rodników przez wyciągi z papryki może mieć wpływ metoda ekstrakcji, a także typ rozpuszczalnika. W badaniu własnym ekstrakty w stężonym etanolu wykazywały wyższą zdolność do zmiatania wolnych rodników, mierzoną metodą DPPH, w porównaniu z wodnymi. Nieco odmienne wyniki uzyskali Kim i wsp., którzy stwierdzili ponad 3-krotnie niższą aktywność antyoksydacyjną ekstraktów etanolowych papryki w porównaniu z wodnymi [6]. Należy jednak zaznaczyć, że autorzy ci wykorzystywali do analizy paprykę słodką, która może mieć odmienne właściwości przeciwutleniające niż papryka ostra chili. Tezę taką potwierdzają Sora i wsp., którzy badali zdolności przeciwrodnikowe 6 typów papryki (ostrej i słodkiej). Poddali oni analizie ekstrakty etanolowe, wykonane osobno zarówno dla okrywy nasiennej, jak i samych nasion. W badaniu okazało się, że działanie przeciwutleniające jest bardzo zróżnicowane w zależności od odmiany papryki, a także części owocu. Najwyższą aktywnością charakteryzowały się nasiona pochodzące z gatunków ostrych papryki: red habanero $(16,26 \mu \mathrm{mol}$ troloksu/g surowca), orange habanero $(15,64 \mu \mathrm{mol}$ troloksu/g surowca) oraz malagueta $(15,06 \mu \mathrm{mol}$ troloksu/g surowca), co może sugerować działanie antyoksydacyjne kapsaicyny, która znajduje się w dużej ilości w nasionach papryk odmian ostrych. Dużo niższą zdolnością przeciwutleniającą cechował się ekstrakt z okrywy nasiennej, przy czym najwyższą wartość zaobserwowano dla odmiany ostrej malagueta (3,09 $\mu$ mol troloksu/g surowca) [21]. Chávez-Mendoza i wsp. podają, że na działanie przeciwrodnikowe ma również wpływ data zbioru owoców papryki - zbiory pozyskane we wrześniu mają najwyższą aktywność antyoksydacyjną w porównaniu z innymi miesiącami, np. lipcem czy sierpniem. Należy dodać, że autorzy ci analizowali różne odmiany papryki słodkiej i ostrej [4].

W badaniu własnym aktywność antyoksydacyjna, mierzona metodą FRAP oceniającą zdolność do redukcji jonów żelaza $\mathrm{Fe}^{3+}$ do $\mathrm{Fe}^{2+}$, była zróżnicowana w zależności od typu rozpuszczalnika i czasu ekstrakcji. Najwyższą wartość w przypadku tej metody wykazano dla wyciągów ekstrahowanych przez 60 min stężonym alkoholem izopropylowym $(2,73 \pm 0,39 \mathrm{mg}$ $\mathrm{FeSO}_{4} /$ g surowca) - rycina 3. Rozbieżne wyniki dotyczące zdolności redukcyjnej mierzonej metodą FRAP uzyskali Sora i wsp. Badając ekstrakty etanolowe różnych rodzajów papryki, uzyskali wyniki w zakresie 3,99-21,17 $\mu \mathrm{mol}$ troloksu/g surowca. Najwyższą wartością charakteryzowała się odmiana ostra malagueta. Autorzy badali również nasiona. Ekstrakty odmiany red habanero osiągnęły najwyższą wartość, bo aż 82,67 $\mu \mathrm{mol}$ troloksu/g [21].

Podsumowując, owoce papryki okazują się być cennym surowcem, którego aktywność antyoksydacyjna może być uzależniona od wielu czynników. Z badań własnych wynika, że na działanie przeciwutleniające otrzymanych wyciągów może mieć wpływ zarówno zastosowany rozpuszczalnik, jak i czas ekstrakcji. Owoc pieprzowca stosowany jest często zewnętrznie w postaci preparatów nanoszonych na skórę w celu jej rozgrzania, drażniąc zakończenia nerwów czuciowych skóry oraz otaczające tkanki, w których powoduje miejscowe przekrwienie. Alkoholowe i suche wyciągi z papryki chili są składnikiem wielu maści, a także plastrów, wykorzystywanych głównie w nerwobólach i bólach reumatycznych, zaś substancją wykazującą takie działanie jest kapsaicyna, która ma również właściwości antyoksydacyjne [9]. Celowa więc wydaje się ocena wpływu zastosowanych rozpuszczalników do ekstrakcji owoców papryki rocznej, z uwzględnieniem czasu ekstrakcji, w celu otrzymania wyciągu o najbardziej optymalnych właściwościach, który mógłby być wykorzystany w przemyśle farmaceutycznym i kosmetycznym.

\section{WNIOSKI}

1. Owoce papryki żółtej charakteryzowały się różną aktywnością antyoksydacyjną, oznaczoną metodą DPPH oraz FRAP.

2. Najcenniejszymi ekstraktami pod względem zdolności do zmiatania wolnych rodników okazały się wyciągi w stężonym metanolu niezależnie od czasu ekstrakcji.

3. Wyciągi wodne z badanego surowca okazały się mieć umiarkowane działanie przeciwutleniające, co stwierdzono zarówno metodą DPPH, jak i FRAP. 
4. Owoce papryki żółtej zawierają w dużej ilości barwniki asymilacyjne, wśród których stwierdzono najwięcej karotenoidów.

5. Właściwości przeciwutleniające badanego surowca wskazują na możliwość wykorzystania go w przemyśle farmaceutycznym oraz kosmetycznym.

\section{PIŚMIENNICTWO}

1. Blanco-Ríos AK, Medina-Juárez LÁ, González-Aguilar GA, Gámez-Meza $\mathrm{N}$. Antioxidant activity of the phenolic and oily fractions of different sweet bell peppers. J Mex Chem Soc 2013;57(2):137-43.

2. Igbokwe GE, Aniakor GC, Anagonye CO. Determination of $\beta$-carotene and vitamin $C$ content of fresh green pepper (Capsicum annuum), fresh red pepper (Capsicum annuum) and fresh tomatoes (Solanum lycopersicum) fruits. Bioscientist 2013;1(1):89-93.

3. Shotorbani N, Jamei, R, Heidari R. Antioxidant activities of two sweet pepper Capsicum annuum L. varieties phenolic extracts and the effects of thermal treatment. Avicenna J Phytomed 2013;3(1):25-34.

4. Chávez-Mendoza C, Sanchez E, Muñoz-Marquez E, Sida-Arreola JP, FloresCordova MA. Bioactive compounds and antioxidant activity in different grafted varieties of bell pepper. Antioxidants 2015;4(2):427-46.

5. Sun T, Xu Z, Wu CT, Janes M, Prinyawiwatkul W, No HK. Antioxidant activities of different colored sweet bell peppers (Capsicum annuum L.). J Food Sci 2007;72(2):98-102. doi: 10.1111/j.1750-3841.2006.00245.x.

6. Kim JS, An GC, Park JS, Lim YP, Kim S. Carotenoid profiling from 27 types of paprika (Capsicum annuum L.) with different colors, shapes, and cultivation methods. Food Chem 2016;201:64-71. doi: 10.1016/j.foodchem.2016.01.041.

7. Paradiković N, Vinković T, Vinković-Vrček I, Žuntar I, Bojić M, MedićŠarić M. Effect of natural biostimulants on yield and nutritional quality: an example of sweet yellow pepper (Capsicum annuum L.) plants. J Sci Food Agric 2011;91(12):2146-52. doi: 10.1002/jsfa.4431.

8. Oboh G, Rocha TBJ. Distribution and antioxidant activity of polyphenols in ripe and unripe tree pepper (Capsicum pubescens). J Food Biochem 2007;31:456-73. doi: 10.1111/j.1745-4514.2007.00123.x.

9. Pieńko T. Kapsaicyna - właściwości, zastosowania i perspektywy. Biul Wydz Farm WUM 2013;2:11-7.
10. Muzykiewicz A, Zielonka-Brzezicka J, Klimowicz A, Florkowska K. Jarząb pospolity (Sorbus aucuparia L.) jako źródło składników o potencjalnym działaniu antyoksydacyjnym - porównanie właściwości przeciwutleniających ekstraktów z liści, kwiatów i owoców. Probl Hig Epidemiol 2017;98(2):125-32.

11. Zielonka-Brzezicka J, Nowak A, Zielińska M, Klimowicz A. Porównanie właściwości przeciwutleniających wybranych części maliny właściwej (Rubus idaeus) i jeżyny europejskiej (Rubus fruticosus). Pomeranian J Life Sci 2016;62(4):52-9. doi: 10.21164/pomjlifesci269.

12. Nowak A, Zielonka-Brzezicka J, Pechaiko D, Tkacz M, Klimowicz A. Ocena właściwości antyoksydacyjnych liści Ginkgo biloba L. po zakończeniu wegetacji. Pomeranian J Life Sci 2017;63(1):9-15. doi: 10.21164/pomjlifesci.222.

13. Arnon DJ, Allen MB, Whatley F. Photosynthesis by isolated chloroplast. IV. General concept and comparison of three photochemical reaction. Biochim Biophys Acta 1956;20(3):449-61.

14. Lichtenthaler HK, Wellburn AR. Determinations of total carotenoids and chlorophyll a and b of leaf extracts in different solvents. Biochem Soc Trans 1983;11(5):591-2. doi: 10.1042/bst0110591.

15. Nadeem M, Anjum FM, Khan MR, Saeed M, Riaz A. Antioxidant potential of bell pepper (Capsicum annuum L.). Pak J Food Sci 2014;21(1-4): 45-51.

16. Materska M, Perucka I. Antioxidant activity of the main phenolic compounds isolated from hot pepper fruit (Capsicum annuum L.). J Agric Food Chem 2005;53(5):1750-6. doi: 10.1021/jf035331k.

17. Stahl W, Sies H. Antioxidant activity of carotenoids. Mol Aspects Med 2003;24(6):345-51. doi: 10.1016/S0098-2997(03)00030-X.

18. Krinsky NI. Carotenoids as antioxidants. Nutrition 2001;17(10):815-7. doi: 10.1016/S0899-9007(01)00651-7.

19. Witrowa-Rajchert D, Hankus M, Pawlak E. Wpływ metody suszenia na zawartość chlorofilu i barwę oregano oraz bazylii. Inż Ap Chem 2009;48(1):70-1.

20. Borowski J, Szajdek A, Borowska EJ. Charakterystyka chemiczna i aktywność biologiczna warzyw z terenu Olsztyna. Bromat Chem Toksykol 2008;41:333-7.

21. Sora GT, Haminiuk CW, da Silva MV, Zieliński AA, Gonçalves GA, Bracht A, et al. A comparative study of the capsaicinoid and phenolic contents and in vitro antioxidant activities of peppers of the genus Capsicum: an application of chemometrics. J Food Sci Technol 2015;52(12):8086-94. doi: 10.1007/s13197-015-1935-8. 